\title{
Gambaran Intervensi Perawat dalam Asuhan Keperawatan Pasien Tuberkulosis Paru di Rumah Sakit
}

\author{
Muhammad Rofi' ${ }^{\prime}{ }^{*}$, Bambang Edi Warsito' ${ }^{1}$, Agus Santoso ${ }^{1}$, Sarah Ulliya ${ }^{1}$ \\ ${ }^{1}$ Departemen Ilmu Keperawatan Fakultas Kedokteran, Universitas Diponegoro, Semarang, Indonesia \\ muhamadrofiiundip76@gmail.com
}

\begin{abstract}
Introduction: The nurses' role within nursing care of tuberculosis patients in hospitals is very important. Nurses problem are preparing nursing interventions in patients with pulmonary tuberculosis rarely use the standard Nursing Intervention Classification (NIC). Independent nursing interventions are not in accordance with the diagnoses established by nurses, so the impact on the implementation needed by patients is not in accordance with the problems occured. Collaborative intervention is mostly carried out by nurses compared to independent intervention. Nurses must arrange nursing interventions based on the standard of nursing diagnoses that are enforced. The objective study was to describe the interventions compiled by nurses at the hospital.

Methods: Research design was qualitative research with observational approach. Sample was 100 nurse's documentastions of pulmonary tuberculosis patient in TB MDR ward. Data analysis used language and text analysis with content analysis.

Results: The results research was the highest 10 interventions written by nurses is intervention about observe general condition of patient was 83 times, collaboration with doctor's therapy was 54 times, give comfort position was 54 times, give therapy was 47 times, check vital signs regulerly was 40 times, give oxigen was 34 times, advise to bedrest was 30 times, teach to effective cough was 25 times, Give position semi fowler was $15 \%$ times, and teach to deep breath was 15 times.

Conclusion: Nurses must improve their skills and knowledge in preparing treatment plans, because the interventions that have been prepared have not been optimal for dealing with patient problems in hospitals. Interventions to improve patient knowledge and abilities in the management of the disease are important to give to patients.
\end{abstract}

Keywords: Intervention, Nurses, Patient, Pulmonary Tuberculosis.

\begin{abstract}
Abstrak
Pendahuluan: Perawat berperan penting dalam perawatan pasien tuberkulosis di rumah sakit. Permasalahan yang muncul pada perawat adalah ketika menyusun intervensi keperawatan pada pasien tuberkulosis paru jarang yang menggunakan standar Nursing Intervention Classification (NIC). Intervensi keperawatan mandiri tidak sesuai dengan diagnosa yang ditegakkan oleh perawat, sehingga berdampak pada implementasi yang dibutuhkan oleh pasien tidak sesuai dengan masalah yang dialami. Intervensi kolaborasi lebih banyak dilakukan oleh perawat dibandingkan dengan intervensi mandiri. Perawat harus menyusun intervensi keperawatan berdasarkan pada standar intervensi diagnosa keperawatan yang ditegakkan. Penelitian tentang intervensi perawat pada pasien TBC paru belum ada. Tujuan penelitian ini adalah untuk mengetahui gambaran intervensi yang disusun perawat di rumah sakit.
\end{abstract}


Metode: Desain penelitian adalah kualitatif dengan menggunakan pendekatan observasional. Jumlah sampel yaitu 100 dokumentasi pasien TBC paru di ruang TBC MDR. Analisa data dengan menggunakan analisis teks dan bahasa yaitu content analysis.

Hasil: Hasil penelitian adalah ada 10 intervensi terbanyak yang dituliskan perawat yaitu kalimat "Observasi Keadaan Umum pasien" sebanyak 83 kali, kalimat "Kolaborasi dengan terapi dokter" sebanyak 54 kali, kalimat "Beri posisi nyaman" sebanyak 54 kali, kalimat "Berikan terapi" sebanyak 47 kali, kalimat "Gali Tanda-tanda vital berkala" sebanyak 40 kali, kalimat "Beri Oksigen" sebanyak 34 kali, kalimat "Anjurkan bedrest" sebanyak 30 kali, kalimat "Ajarkan batuk efektif" sebanyak 25 kali, kalimat "Posisikan semi fowler" sebanyak 15\%, dan kalimat "Ajarkan nafas dalam" sebanyak 15 kali.

Kesimpulan: Perawat harus meningkatkan ketrampilan dan pengetahuan dalam menyusun rencana perawatan, karena intervensi yang disusun belum optimal untuk mengatasi masalah pasien di RS. Intervensi untuk peningkatan pengetahuan dan kemampuan pasien dalam manajemen penyakitnya adalah penting untuk diberikan pada pasien, agar mengurangi angka putus obat.

Kata Kunci: Intervensi, Perawat, Pasien, Tuberkulosis Paru

\section{PENDAHULUAN}

Penyakit tuberkulosis adalah penyakit menular yang sangat berbahaya dan penyakit ini merupakan salah satu masalah kesehatan yang paling besar di seluruh dunia. Penyakit ini juga merupakan penyebab angka kematian dan angak kesakitan yang tertinggi pada negaranegara berkembang, seperti Indonesia. Tuberkulosis (TBC) adalah sebuah penyakit infeksi yang terjadi di seluruh dunia, pada tahun 2009 menginfeksi 9,4 juta pasien dan hampir 14 juta orang hidup dengan penyakit TBC (World Health Organization [WHO], 2010).

TBC menjadi masalah kesehatan dan masalah masyarakat, faktor-faktor seperti sosial ekonomi dan status nutrisi, persepsi tentang penyakit, perilaku kesehatan dan akses pelayanan kesehatan mempengaruhi frekuensi dan prognosis penyakit tuberkulosis (Rabo, El-zeftawy \& AboGad, 2015). Salah satu alasan terjadinya peningkatan TBC secara umum adalah kurang baiknya pelayanan kesehatan dan pengelolaan pasien yang tidak tepat. TBC terkadang dikaitkan dengan stigma negatif dari perilaku perawat yang menjauhi atau menghindari pasien TBC untuk mencegah penularan TBC. Perawat mempunyai peran yang sangat penting pada program pengawasan TBC. Pengobatan di rumah sakit paling baik diawasi oleh perawat, karena perawat secara rutin bertemu dan selama 24 jam bersama dengan pasien.

Upaya untuk mengatasi hambatan yang terjadi pada kepatuhan pasien TBC terfokus pada sistem pelayanan kesehatan dan pada pasien itu sendiri. Kegiatan untuk mengatasi hambatan yang terjadi pada kepatuhan pasien adalah melalui program peningkatan terapi langsung yang bisa diamati dan terapi pencegahan. Pada pasien TBC, upaya yang harus dilakukan adalah mengembangkan pengetahuan bersama dan rencana perawatan untuk TBC, yang meliputi keyakinan terhadap dan praktik kesehatan. Kualitas hubungan antara pemberi layanan kesehatan terutama perawat dan pasien sangat penting untuk upaya pendidikan yang mendukung kepatuhan (Orr, 2011).

Peran perawat sebagai pemberi pelayanan terkadang tidak sesuai dengan standar dan kurang optimal dalam memberikan pelayanan kepada pasien. 
Hasil penelitian menunjukkan bahwa mayoritas $(89,2 \%)$ pasien TBC melaporkan bahwa prosedur dan pemeriksaan TBC tidak dilakukan, hanya $51,4 \%$ pasien TBC yang mengatakan ketersediaan fasilitas pelayanan, $48,6 \%$ pasien dan pemberi pelayanan melakukan interaksi dan konseling, serta hanya $37,8 \%$ pasien TBC yang diberikan informasi tentang TBC dan pengobatannya (Rabo et al., 2015). Perawat masih kurang optimal dalam melakukan konseling kepada pasien, dan ini merupakan bagian intervensi perawat pada pasien TBC. Intervensi edukasi pada pasien dalam penelitian ini juga belum optimal diberikan pada pasien, padahal peran perawat sebagai edukator adalah peran penting dalam memberikan asuhan keperawatan.

Perawat dalam menyusun intervensi keperawatan tidak lengkap dan tidak sesuai dengan standar Nursing Intervention Classification (NIC) (Butcher, Howard, Gloria, Dochterman, \& Wagner, 2013). NIC sebagai standar intervensi keperawatan secara internasional sudah sangat baik digunakan dalam intervensi keperawatan pada pasien. Disamping juga, perawat dalam menyusun intervensi keperawatan belum secara maksimal mengacu pada standar intervensi keperawatan di Indonesia. Penerapan standar asuhan keperawatan pada pasien TBC adalah sangat perlu dilakukan oleh perawat, agar yang dilakukan oleh perawat berdasarkan pada ilmu pengetahuan keperawatan. Standar yang dikembangkan bisa sebagai panduan referensi untuk mengimplementasikan layanan ideal perawatan pada pasien TBC (El-kader, Ghazi, Ramadan, \& Soliman, 2011).

Hasil pengamatan pada penulisan intervensi keperawatan ditemukan pada perawat di rumah sakit bahwa intervensi keperawatan mandiri tidak sesuai dengan standar intervensi pada masalah yang akan diatasi, sehingga berdampak pada implementasi yang dibutuhkan oleh pasien tidak sesuai dengan masalah yang dialami. Intervensi keperawatan kolaborasi lebih banyak dilakukan oleh perawat dibandingkan dengan intervensi keperawatan mandiri. Intervensi perawat masih banyak bergantung pada tindakan medis, sehingga otonomi perawat kurang optimal dilakukan pada pemberian asuhan keperawatan. Perawat seharusnya menyusun intervensi keperawatan berdasarkan pada standar intervensi diagnosa keperawatan yang ditegakkan.

Penelitian sebelumnya tentang intervensi keperawatan adalah penelitian tentang efektifitas intervensi keperawatan pada pasien gagal jantung dengan menggunakan NIC-NOC, yang mengukur tentang penerapan keberhasilan intervensi yang dilakukan (Azzolin et al., 2013). Penelitian ini berbeda pada metode penelitian dan juga tujuan yang dicapai. Penelitian tentang intervensi perawat pada pasien TBC lebih menggambarkan apa saja yang dilakukan perawat dalam menyusun intervensi pada pasien tersebut.

Penelitian lain yang berbeda dengan penelitian ini adalah penelitian dari Gimenes, Motta, Silva, Gobbo, Atila, Carvalho (2017). Dimana penelitian ini mengidentifikasi intervensi keperawatan yang paling akurat dan paling sering digunakan pada diagnosa NANDA (North American Nursing Diagnosis Association) (Gimenes et al., 2017). Sehingga jelas perbedaannya, penelitian ini lebih menggambarkan tentang intervensi yang sering disusun perawat pada kasus tuberkulosis paru, bukan berdasarkan diagnosis NANDA.

Penelitian tentang gambaran intervensi perawat pada pasien TBC paru di rumah sakit belum ada. Penelitian lain 
yang berbeda tentang intervensi yaitu tentang dampak integrasi intervensi keperawatan pada nyeri dengan pasien penyakit kritis (Papathanassoglou et al., 2018), penelitian lain yang berbeda tentang akurasi rencana perawatan dan penggunaan standarisasi bahasa keperawatan (Johnson, Edward, \& Giandinoto, 2018). Penelitian ini berbeda dengan penelitian sebelumnya, sehingga ditemukan permasalahan "Bagaimana perawat melakukan intervensi keperawatan pada pasien TBC paru?" Tujuan penelitian ini adalah untuk mengetahui gambaran intervensi keperawatan pada pasien TBC paru yang dilakukan pada perawat.

\section{METODE}

Penelitian dilaksanakan di ruang rawat inap sebuah rumah sakit pemerintah di Salatiga. Waktu pengumpulan data selama 3 bulan. Data diambil di ruang khusus rawat inap penderita TBC paru di rumah sakit. Penelitian ini menggunakan desain kualitatif dengan melakukan observasi langsung pada catatan medis pasien dengan TBC paru. Hal-hal yang diobservasi dalam penelitian adalah catatan perawat tentang intervensi keperawatan pada pasien TBC Paru. Populasi penelitian ini adalah dokumentasi intervensi asuhan keperawatan pasien TBC paru. Sampel penelitian ini sebanyak 100 dokumentasi asuhan keperawatan pasien TBC paru. Teknik pengambilan sampel dokumentasi asuhan keperawatan adalah dengan cara nonprobability sampling yaitu purposive sampling jenuh, yaitu dokumentasi pasien TBC paru selama 3 bulan diambil semua sebagai sampel. Pasien dengan penyakit pernapasan lainnya, yang bukan TBC paru tidak diambil sebagai sampel dalam penelitian ini. Analisa data dalam penelitian ini adalah dengan menggunakan metode analisis teks dan bahasa yaitu content analysis.

\section{HASIL}

Hasil penelitian ini adalah gambaran dokumentasi intervensi keperawatan yang dilakukan oleh perawat di rumah sakit. Gambaran dokumentasi intervensi keperawatan pada pasien TBC Paru dapat dilihat pada tabel 1 .

Hasil penelitian pada tabel 1 menunjukkan bahwa perawat menyusun intervensi keperawatan pada pasien TBC paru untuk intervensi kebutuhan oksigenasi paling banyak adalah "beri $\mathrm{O}_{2}$ " sebanyak 34 kali dan urutan kedua adalah "ajarkan batuk efektif" sebanyak 25 kali, sedangkan intervensi kebutuhan nutrisi paling banyak adalah "anjurkan makan sedikit sering" sebanyak empat kali, intervensi kebutuhan aman nyaman paling banyak adalah "beri posisi nyaman" yaitu $54 \mathrm{kali}$, intervensi kebutuhan aktivitas paling banyak adalah "bantu posisi" sebanyak tiga kali, intervensi kebutuhan istirahat tidur paling banyak adalah "anjurkan bedrest" sebanyak tiga puluh kali, dan intervensi tindakan lainnya paling banyak adalah "observasi kondisi umum (KU) pasien" sebanyak 83 kali.

\section{PEMBAHASAN}

Intervensi keperawatan pada pasien TBC paru yang disusun perawat yang terbanyak adalah intervensi tentang observasi keadaan umum pasien (83 kali). Intervensi tentang observasi keadaan umum pasien tidak sesuai dengan intervensi pada diagnosa bersihan jalan nafas tidak efektif, pola nafas tidak efektif, intoleransi aktivitas, nyeri akut, dan hipertermi. Perawat lebih banyak 
menuliskan intervensi ini lebih banyak yang tidak sesuai dengan diagnosa keperawatan yang muncul. Menurut Dolak dan Tothova, intervensi yang sering digunakan untuk diagnosa pola napas tidak efektif adalah monitoring pernafasan, bantuan ventilasi, fisioterapi dada, suction jalan napas, dan manajemen jalan napas (Dolak \& Tóthová, 2014). Intervensi tentang observasi keadaan umum pasien dituliskan pada diagnosa risiko aspirasi dan intervensi ini sesuai dengan intervensi pada diagnosa risiko aspirasi (Bulechek, Butcher, Dochterman, \& Wagner, 2013; Carpenito, 2010; Doenges, Moorhouse, \& Murr, 2010a, 2010b; Newfield, Hinz, Tilley, \& Sridaromont, 2007).

Tabel 1. Gambaran Intervensi Keperawatan Pasien Tuberkulosis Paru di Rumah Sakit Pemerintah di Salatiga $(n=100)$.

\begin{tabular}{|c|c|c|}
\hline Kebutuhan & Intervensi Keperawatan & $\begin{array}{l}\text { Jumlah } \\
\text { Tulisan }\end{array}$ \\
\hline \multirow[t]{17}{*}{ Oksigenasi } & 1. Beri $\mathrm{O}_{2}$ & 34 \\
\hline & 2. Ajarkan batuk efektif & 25 \\
\hline & 3. Posisikan semifowler & 15 \\
\hline & 4. Ajarkan nafpas dalam & 15 \\
\hline & $\begin{array}{l}\text { 5. Anjurkan pasien } \\
\text { minum hangat }\end{array}$ & 9 \\
\hline & $\begin{array}{l}\text { 6. Kaji bersihan jalan } \\
\text { napas }\end{array}$ & 9 \\
\hline & 7. Latih batuk efektif & 8 \\
\hline & 8. Kaji pola nafas & 4 \\
\hline & 9. Anjurkan nafas dalam & 4 \\
\hline & $\begin{array}{l}\text { 10. Anjurkan membuang } \\
\text { dahak pada sputum pot }\end{array}$ & 4 \\
\hline & $\begin{array}{l}\text { 11. Anjurkan memakai } \\
\text { masker }\end{array}$ & 3 \\
\hline & 12. Kaji suara napas & 2 \\
\hline & $\begin{array}{l}\text { 13. Kaji kebutuhan } \\
\text { oksigen }\end{array}$ & 2 \\
\hline & 14. Patenkan oksigenasi & 2 \\
\hline & $\begin{array}{l}\text { 15. Observasi penggunaan } \\
\text { alat bantu pernafasan }\end{array}$ & 1 \\
\hline & $\begin{array}{l}\text { 16. Kaji pola batuk } \\
\text { berdarah }\end{array}$ & 1 \\
\hline & 17. Kaji penyebab jalan & 1 \\
\hline
\end{tabular}

napas tidak efektif

18. Observasi adanya sianosis

19. Observasi tanda-tanda sianosis

$\begin{array}{lll}\begin{array}{l}\text { Nutrisi dan } \\ \text { cairan }\end{array} & 1 . & \begin{array}{l}\text { Anjurkan makan } \\ \text { sedikit sering }\end{array} \\ & 2 . & \begin{array}{l}\text { Anjurkan minum } \\ \text { banyak }\end{array} \\ & \text { 3. } & \begin{array}{l}\text { Anjurkan yang tidak } \\ \text { pedas }\end{array}\end{array}$

nyaman

1. Beri posisi nyaman

2. Gali TTV berkala

3. Kaji skala nyeri

4. Beri suasana nyaman

Aktifitas

1. Bantu posisi

2. Atur posisi pasien

3. Anjurkan aktifitas dengan bantuan

4. Anjurkan mobilisasi sedikit demi sedikit

Istirahat
Tidur

1. Anjurkan bedrest

2. Motivasi rileks

3. Anjurkan rileks

Tindakan

1. Observasi KU pasien lainnya

2. Kolaborasi dengan terapi dokter

3. Berikan terapi

4. Operan jaga

5. Monitor tetesan infus

6. Catat pengobatan TBC sebelumnya

7. Atur tetesan infus

Intervensi keperawatan tentang kolaborasi dengan terapi dokter disusun perawat sebanyak 54 kali. Intervensi ini adalah intervensi dependen. Intervensi ini dituliskan perawat tidak untuk diagnosa keperawatan tertentu, tapi setiap diagnosa apapun dituliskan intervensi ini. Intervensi tentang kolaborasi dengan dokter sesuai dengan intervensi pada diagnosa bersihan jalan napas tidak efektif, nyeri akut, dan hipertermi (Bulechek, Butcher, \& Dochterman, Wagner, 2013; Carpenito, 2010; Doenges, Moorhouse, \& Murr, 2010a, 2010b; Newfield, Hinz, Tilley, \& Sridaromont, 2007). 
Intervensi keperawatan tentang beri posisi nyaman disusun perawat sebanyak 54 kali. Intervensi tentang kolaborasi dengan dokter sesuai dengan intervensi pada diagnosa bersihan jalan napas tidak efektif, pola napas tidak efektif, intoleransi aktivitas, dan risiko aspirasi (Bulechek, Butcher, Dochterman, \& Wagner, 2013; Carpenito, 2010; Doenges, Moorhouse, \& Murr, 2010a, 2010b; Newfield, Hinz, Tilley, \& Sridaromont, 2007).

Intervensi keperawatan tentang berikan terapi disusun perawat sebanyak 47 kali. Intervensi tentang berikan terapi sesuai dengan intervensi pada diagnosa bersihan jalan nafas tidak efektif, nyeri akut, dan hipertermi (Bulechek, Butcher, Dochterman, \& Wagner, 2013; Carpenito, 2010; Doenges, Moorhouse, \& Murr, 2010a, 2010b; Newfield, Hinz, Tilley, \& Sridaromont, 2007).

Intervensi keperawatan tentang gali tanda-tanda vital berkala disusun perawat sebanyak 40 kali. Kata gali tanda-tanda vital berkal adalah salah, yang betul adalah monitor tanda-tanda vital. Intervensi tentang monitor tanda-tanda vital sesuai dengan intervensi pada diagnosa bersihan jalan nafas tidak efektif, nyeri akut, intoleransi aktifitas, dan hipertermi (Bulechek, Butcher, Dochterman, \& Wagner, 2013; Carpenito, 2010; Doenges, Moorhouse, \& Murr, 2010a, 2010b; Newfield, Hinz, Tilley, \& Sridaromont, 2007).

Intervensi keperawatan tentang beri $\mathrm{O} 2$ disusun perawat sebanyak 34 kali. Intervensi tentang beri $\mathrm{O} 2$ sesuai dengan intervensi pada diagnosa bersihan jalan nafas tidak efektif dan pola nafas tidak efektif (Bulechek, Butcher, \& Dochterman, \& Wagner, 2013; Carpenito, 2010; Doenges, Moorhouse, \& Murr, 2010a, 2010b; Newfield, Hinz, Tilley, \& Sridaromont, 2007).
Intervensi keperawatan tentang anjurkan bedrest disusun perawat sebanyak $30 \%$. Intervensi tentang anjurkan bedrest sesuai dengan intervensi pada diagnosa intoleransi aktifitas (Bulechek, Butcher, \& Dochterman, \& Wagner, 2013; Carpenito, 2010; Doenges, Moorhouse, \& Murr, 2010a, 2010b).

Intervensi keperawatan tentang ajarkan batuk efektif disusun perawat sebanyak 25 kali. Intervensi tentang ajarkan batuk efektif sesuai dengan intervensi pada diagnosa bersihan jalan nafas tidak efektif dan pola nafas tidak efektif (Bulechek, Butcher, \& Dochterman, 2013; Carpenito, 2010; Doenges, Moorhouse, \& Murr, 2010a, 2010b; Newfield, Hinz, Tilley, \& Sridaromont, 2007).

Intervensi keperawatan tentang posisikan semi fowler disusun perawat sebanyak lima belas kali. Intervensi tentang posisikan semi fowler sesuai dengan intervensi pada diagnosa bersihan jalan napas tidak efektif, pola napas tidak efektif, dan risiko aspirasi (Bulechek, Butcher, \& Dochterman, 2013; Carpenito, 2010; Doenges, Moorhouse, \& Murr, 2010a, 2010b; Newfield, Hinz, Tilley, \& Sridaromont, 2007).

Intervensi keperawatan tentang ajarkan napas dalam disusun perawat sebanyak lima belas kali. Intervensi tentang ajarkan napas dalam sesuai dengan intervensi pada diagnosa bersihan jalan napas tidak efektif, pola napas tidak efektif, dan nyeri akut (Bulechek, Butcher, \& Dochterman, 2013; Carpenito, 2010; Doenges, Moorhouse, \& Murr, 2010a, 2010b; Newfield, Hinz, Tilley, \& Sridaromont, 2007).

Masalah lain yang sangat penting untuk dilakukan intervensi keperawatan adalah masalah risiko infeksi (penyebaran atau aktivasi ulang). Perawat dapat 
menyusun intervensi berupa identifikasi orang lain yeng berisiko, anjurkan pasien untuk batuk atau bersin dan mengeluarkan pada tisu dan menghindari meludah; anjurkan kontrol infeksi dengan memakai masker; dan identifikasi faktor risiko individu terhadap pengaktifan berulang TBC (Bulechek, Butcher, Dochterman, \& Wagner, 2013; Carpenito, 2010; Doenges, Moorhouse, \& Murr, 2010a, 2010b; Newfield, Hinz, Tilley, \& Sridaromont, 2007).

Perawat harus lebih teliti untuk menyusun intervensi keperawatan. Masalah nutrisi pasien TBC paru harus disusun dengan baik. Intervensi keperawatan masalah nutrisi yang dapat disusun oleh perawat adalah kaji status nutrisi dan pola diet pasien, kaji anoreksia, mual dan muntah, berikan perawatan mulut, dan motivasi makan sedikit tapi sering dan tinggi proten dan karbohidrat (Bulechek, Butcher, Dochterman, \& Wagner, 2013; Carpenito, 2010; Doenges, Moorhouse, \& Murr, 2010a, 2010b; Newfield, Hinz, Tilley, \& Sridaromont, 2007). Hasil penelitian ini menunjukkan bahwa perawat jarang membuat perencanaan tentang nutrisi bagi pasien.

Masalah pengetahuan juga penting pasien TBC paru. Intervensi keperawatan yang bisa direncanakan adalah ajarkan makanan tinggi protein dan karbohidrat; ajarkan untuk jadwal obat, dosis, frekuensi pemberian, kerja yang diharapkan, dan alasan pengobatan lama; ajarkan bahaya rokok; dan jelaskan efek samping obat (Bulechek, Butcher, Dochterman, \& Wagner, 2013; Carpenito, 2010; Doenges, Moorhouse, \& Murr, 2010a, 2010b; Newfield, Hinz, Tilley, \& Sridaromont, 2007).

\section{KESIMPULAN}

Kesimpulan penelitian adalah terdapat sepuluh intervensi yang sering dituliskan perawat adalah observasi keadaan umum pasien, kolaborasi dengan terapi dokter, beri posisi nyaman, berikan terapi, cek tanda-tanda vital berkala, beri oksigen, anjurkan bedrest, ajarkan batuk efektif, posisikan semi fowler, dan ajarkan nafas dalam. Perawat harus meningkatkan ketrampilan dan pengetahuan dalam menyusun rencana perawatan, karena intervensi yang disusun belum optimal untuk mengatasi masalah pasien di RS. Intervensi untuk peningkatan pengetahuan dan kemampuan pasien dalam manajemen penyakitnya adalah penting untuk diberikan pada pasien, agar mengurangi angka putus obat.

\section{UCAPAN TERIMAKASIH}

Penulis mengucapkan terima kasih kepada Dekan Fakultas Kedokteran Universitas Diponegoro, Direktur Rumah Sakit Paru dr. Ario Wirawan Salatiga, Perawat Rumah Sakit Paru dr. Ario Wirawan Salatiga. Penulis juga berterima kasih kepada semua orang yang terlibat dalam penelitian ini yang tidak dapat disebutkan satu persatu, atas semua dukungan dan partisipasinya.

\section{DAFTAR PUSTAKA}

Rabo, R. A. M. A., El-zeftawy, A. M. A., \& Abo-Gad, R. A. (2015). Tuberculosis patients' perspective of quality of care provided by nurses after implementing nursing intervention at chest governorate hospitals in Gharbia. IOSR Journal of Nursing and Health Science, 3(6), $27-$ 38.

Azzolin, K., Mussi, C. M., Ruschel, K. B., 
Souza, E. N. De, Lucena, A. D. F., \& Rabelo-silva, E. R. (2013). Effectiveness of nursing interventions in heart failure patients in home care using. Applied Nursing Research, 26(4), 239-244. doi: 10.1016/j.apnr.2013.08.003

Bulechek, G. M, Butcher, H. K., Dochterman, J. M., \& Wagner, C. (2013). Nursing interventions classification (NIC) (6th ed.). Philadelphia.: Elsevier Global Rights.

Butcher, H. K., Gloria M., B., Dochterman, J. M., \& and Wagner, C. M. (2013). Nursing interventions classification (NIC) (6th ed.). St. Louis, Missouri: Elsevier Mosby.

Carpenito, L. J. (2010). Nursing diagnosis: Application to clinical practice (13th ed.). Philadelphia: Lippincott Company.

Doenges, M. E., Moorhouse, M. F., \& Murr, A. C. (2010a). Nurse's pocket guide: Diagnoses, prioritized interventions, and rationales (12th ed.). Philadelphia: F.A. Davis Company.

Doenges M. E., Moorhouse, M. F., \& Murr. A. (2010b). Nursing diagnosis manual: Planning, individualizing, and documenting client care. ( $3^{\text {rd }} \mathrm{ed}$.). Philadelphia: F.A. Davis Company.

Dolak, F., \& Tóthová, V. (2014). Priority interventions from the NIC and expected results from the NOC in patients with a nursing diagnosis of Ineffective breathing pattern, Kontakt, $6, \quad 2-9 . \quad$ doi: 10.1016/j.kontakt.2014.04.001

El-kader, R. G. A. B. D., Ghazi, C. M. K.,
Ramadan, F. A. B. D. E., \& Soliman, S. M. (2011). Development of standard of care for pulmonary tuberculosis for nurses working in chest outpatient clinics. The Medical Journal of Cairo University, 79(2), 139-145.

Gimenes, F. R., Motta, A. P., Silva, P. C., Gobbo, A. F., Atila, E., \& Carvalho, E. C. (2017). Identifying nursing interventions associated with the accuracy used nursing diagnoses for patients with liver cirrhosis 1 . Revista Latino-Americana de Enfermagem, 25(e2933), 1-9. doi:10.1590/15188345.2016.2933

Johnson, L., Edward, K., \& Giandinoto, J. (2018). A systematic literature review of accuracy in nursing care plans and using standardised nursing language. Collegian, 25(3), 355-361. doi: 10.1016/j.colegn.2017.09.006

Newfield, S. A., Hinz MD, Tilley DS, Sridaromont KL, and M. P. (2007). Cox's clinical applications of nursing diagnosis: Adult, child, women's, mental health, gerontic, and home health considerations (5th ed.). Philadelphia: F.A. Davis Company.

Orr, P. (2011). Adherence to tuberculosis care in Canadian Aboriginal populations part 2: A comprehensive approach to fostering adherent behaviour. International Journal of Circumpolar Health, 70(2), 128-140.

Papathanassoglou, E. D., Hadjibalassi, M., Miltiadous, P., Lambrinou, E., Papastavrou, E., Paikousis, L., \& Kyprianou, T. (2018). Effects of an integrative nursing intervention on pain in critically ill patients: A pilot 
Volume 2, No. 2, November 2019 (Hal. 1-9)

Available Online at https://ejournal2.undip.ac.id/index.php/hnhs

clinical trial. American Journal of

Critical Care, 27(3), 172-185. doi:

10.4037/ajec2018271

WHO. (2010). Global Tuberculosis

Control. Geneva. 